DOI: $10.1515 /$ lpts-2016-0039

\title{
INTRODUCTION OF ENERGY AND CLIMATE MITIGATION POLICY ISSUES IN ENERGY - ENVIRONMENT MODEL OF LATVIA
}

\author{
G. Klavs, J. Rekis \\ Institute of Physical Energetics, 11 Krivu Street, Riga, LV-1006, LATVIA \\ e-mail: energy@edi.lv
}

The present research is aimed at contributing to the Latvian national climate policy development by projecting total GHG emissions up to 2030, by evaluating the GHG emission reduction path in the non-ETS sector at different targets set for emissions reduction and by evaluating the obtained results within the context of the obligations defined by the EU 2030 policy framework for climate and energy. The method used in the research was bottom-up, linear programming optimisation model MARKAL code adapted as the MARKALLatvia model with improvements for perfecting the integrated assessment of climate policy. The modelling results in the baseline scenario, reflecting national economic development forecasts and comprising the existing GHG emissions reduction policies and measures, show that in 2030 emissions will increase by $19.1 \%$ compared to 2005 . GHG emissions stabilisation and reduction in 2030, compared to 2005, were researched in respective alternative scenarios. Detailed modelling and analysis of the Latvian situation according to the scenario of non-ETS sector GHG emissions stabilisation and reduction in 2030 compared to 2005 have revealed that to implement a cost effective strategy of GHG emissions reduction first of all a policy should be developed that ensures effective absorption of the available energy efficiency potential in all consumer sectors. The next group of emissions reduction measures includes all non-ETS sectors (industry, services, agriculture, transport, and waste management).

Keywords: bottom-up models, GHG abatement, energy efficiency, nonETS, scenarios.

\section{INTRODUCTION}

Taking into account the EU 2030 policy framework for climate and energy that has set an ambitious target - to reduce the EU domestic greenhouse gas (GHG) emissions in 2030 by at least $40 \%$ compared to 1990, it is important that the member states assess the emissions forecast of the non-ETS sector in 2030, the impact of the planned emissions reduction measures on emissions volume and the possible strategies and costs for reaching the set targets.

In Latvia, a crucial part of the total emissions volume is made by emissions in the non-ETS sectors (GHG emissions from the sectors outside the EU Emission 
Trading Scheme (hereinafter non-ETS sector) that constitute on average $3 / 4$ of the total emissions in the state. In Latvia, the non-ETS share in the total emissions volume is substantially higher than the EU average indicator $58 \%$ [1]. Sources of emissions include the non-ETS sectors of agriculture and transport (except international aviation and international marine transport), and are not covered by the ETS energy, industry, household and waste management sectors. The transport and agriculture sectors gave most of the non-ETS emissions in 2014 (32.8\% and 30.3\%, respectively). The emissions share of the agriculture sector is essentially higher than the average EU indicator. Latvia had the lowest GHG emissions per capita in the EU in 2013 , being almost by $40 \%$ lower than the EU indicator. It is mostly determined by the large share of renewable energy sources (RES) in the gross final consumption of energy that reached $38.7 \%$ in 2014 and ranks second in the EU after Sweden. This indicator is more than twice higher than the average indicator $16 \%$ in the EU in 2014. An essential feature of the Latvian energy sector is the high ratio of district heating (DH). Slightly more than $55 \%$ of dwellings are connected to DH. Households are the biggest consumers and in 2014 their share in the total DH consumption constituted almost $70 \%$. A note should be made that ETS companies supply about $70 \%$ of the required heat in the DH system. Consequently, energy efficiency measures in buildings that at the EU level are believed to be typical GHG emissions reduction measures in the non-ETS sectors leave a vital impact on emissions of the ETS sector in Latvia.

The brief summary above about GHG emissions structure and some indicators in the energy sector and their comparison with the average EU indicators reveals the existing sharp differences between them and the need for assessing the strategies applying national models to reach the GHG emissions targets in Latvia.

\section{MODELLING METHOD AND ASSUMPTIONS}

To model the development of the Latvian energy sector and analyse the strategies for GHG emissions reduction in the non-ETS sector, we use widely-applied partial equilibrium, bottom-up, dynamic, linear programming optimisation model MARKAL code for the energy-environmental system optimisation [2], [3]. By adapting the model to Latvia's circumstances, the MARKAL-Latvia country model has been developed, which is applied to research energy and environment at the national level. The model integrates the end-use sectors and the supply side, holding descriptions of different energy sources and carriers that pass through the stages of energy system - transformation and distribution processes, energy end-use processes in all economic sectors, including a set of technological and energy efficiency options, as well as associated emissions. The approach of MARKAL Elastic Demand is used and a more detailed description of the Latvian model is given [4]. Alongside a very detailed description of the energy system, modelling of GHG emissions in other sectors (agriculture and waste management) and GHG abatement cost curves are presented. GHG emissions in the agriculture and waste management sectors are represented in aggregate, and it gives a possibility for an integrated assessment of the GHG emissions projection scenarios and the optimal strategy for reaching the aims set for Latvia concerning GHG emissions reduction. The developed version of 
the model allows modelling the interaction of the energy and agriculture sectors regarding the resources and energy used and the created and reduced GHG emissions. It includes the calculation of GHG emissions in full cycle use of biomass in energy production, for example, production of biogas and biofuel [5]. It provides a possibility to calculate in one model the created GHG emissions for the production of agricultural biomass and the reduced emissions in the energy sector, when substituting fossil resources. Such an approach gives a possibility to assess more accurately the impact of the implemented renewable energy resource policy upon the total GHG emissions in the country.

The historical import and export prices of energy carriers correspond to the data of the Eurostat external trade data base [8]. The trajectories of future price projections are smooth as to long-term trends; short-term prices may fluctuate relatively widely around the trajectory. The price projections of energy carriers are calculated on the basis of the IEA World Energy Outlook 2014 [9] fossil fuel import price projections from the "Current Policies Scenario".

\section{RESULTS AND ANALYSIS}

A set of scenarios was developed to serve as a basis for calculating GHG emissions projections and assessing the GHG emissions reduction policy and quantitative impact of the measures. The baseline scenario of GHG emissions projections envisages the implementation of those measures that are related to the climate policy and provided in the policy documents drawn by the Latvian government up to 2014 . The same indicators were used in all scenarios to characterise the national economic growth (GDP growth, the development of sectors and industries (value added)), increase of population well-being (growth of private consumption) and demographic growth (see Table1). The scenarios differ in the selected energy and climate policy as well as the implementation or intensity regarding the measures of GHG emissions reduction. A brief characterisation of the scenarios modelled and used for further analysis of the results is given below:

- The baseline scenario aimed at reaching the targets of the existing energy and climate policy in 2020;

- GHG_00 scenario envisaging certain stabilisation of emissions in nonETS sector at the level of 2005 beginning with the year 2030;

- GHG_10 scenario envisaging reduction of emissions by $10 \%$ in the nonETS sector against the level of 2005 beginning with the year 2030;

- Additional scenarios with additional available energy efficiency potentials (the above scenarios marked with E).

Based on assumptions about the changes in the indicators characterising the macroeconomic development by 2030, assumptions on changes in the fuel and energy prices, the energy and climate policies described in the model, the measures to be implemented for GHG emissions reduction the total GHG emission projections were calculated in the developed scenarios, which were further split into the ETS and non-ETS sectors. The table below presents GHG emissions projections were calculated in the non-ETS sector in the baseline and alternative scenarios. 
The Main Macroeconomic Indicators for GHG Emissions Projection in the Baseline Scenario

\begin{tabular}{|l|c|c|c|c|}
\hline & 2020 & 2025 & 2030 & 2035 \\
\hline $\begin{array}{l}\text { Number of population in the } \\
\text { middle of the year, thous. }\end{array}$ & 1938.72 & 1926.85 & 1923.87 & 1924.47 \\
\hline $\begin{array}{l}\text { Annual changes in private } \\
\text { consumption, \% }\end{array}$ & $4.2 \%$ & $4.3 \%$ & $3.3 \%$ & $2.7 \%$ \\
\hline Annual changes of GDP, \% & $4.2 \%$ & $4.3 \%$ & $3.3 \%$ & $2.7 \%$ \\
\hline Agriculture & $2.9 \%$ & $3.8 \%$ & $2.7 \%$ & $2.1 \%$ \\
\hline Services & $4.8 \%$ & $4.6 \%$ & $3.4 \%$ & $2.7 \%$ \\
\hline Industry & $5.1 \%$ & $6.7 \%$ & $5.6 \%$ & $4.4 \%$ \\
\hline
\end{tabular}

Table 2

Summary of the Results on GHG Emissions in the Modelled Scenarios in the Non-ETS Sector

\begin{tabular}{|l|c|c|}
\hline Scenario & $\begin{array}{c}\text { GHG emissions in 2020 against } \\
\text { the level in 2005 }\end{array}$ & $\begin{array}{c}\text { GHG emissions in 2030 against } \\
\text { the level in 2005 }\end{array}$ \\
\hline Baseline scenario & $+4.4 \%$ & $+19.1 \%$ \\
\hline GHG_00 scenario & $+3.7 \%$ & $+0 \%$ \\
\hline GHG_10 scenario & $+3.4 \%$ & $-10 \%$ \\
\hline
\end{tabular}

To have an overall analysis of the volume of GHG emissions reduction in the alternative scenarios, their dynamics and distribution according to the sectors, the obtained modelling results in the alternative scenarios were compared to the results in the modelled baseline scenario. As revealed by the modelling results, the first emissions reduction measures in the alternative scenarios against the baseline scenario are to be implemented by 2020 (see Table 1). In the GHG emissions stabilisation scenario and the GHG emissions reduction scenario against the year 2005 measures with the greatest impact are implemented after 2025.

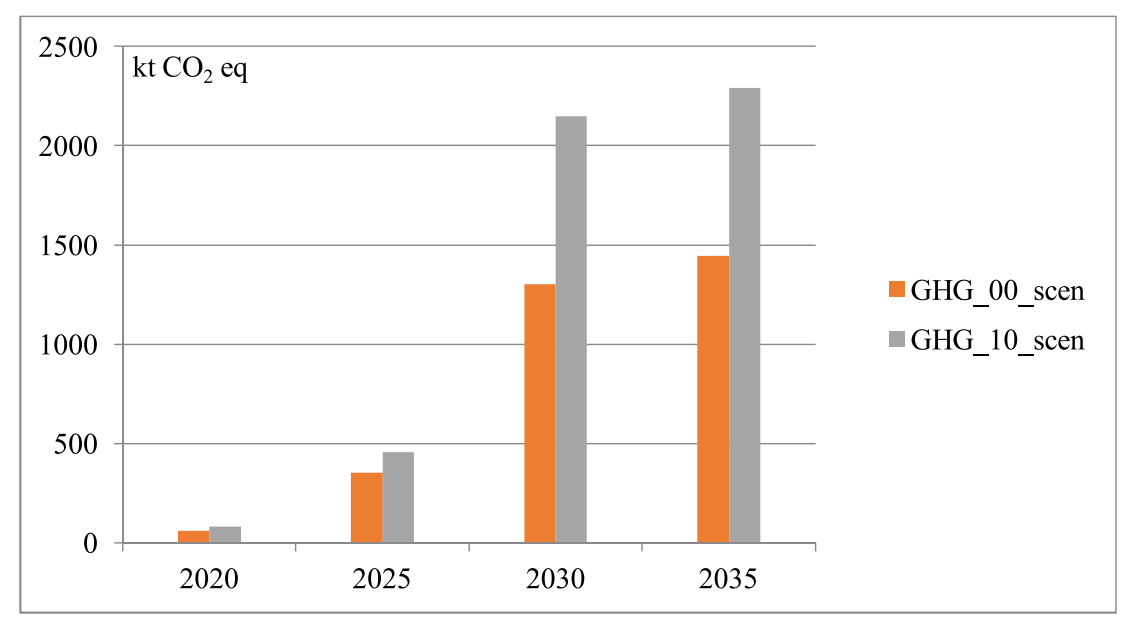

Fig. 1. GHG emissions reduction in the modelled scenarios against the baseline scenario.

The chart below reveals that the scenario on emissions stabilisation in 2030 against 2005 in comparison with the baseline scenario envisages measures of emissions reduction first in the industry (increasing energy efficiency and use of RES) 
followed by the transport and agriculture sectors. Measures of emissions reduction on a smaller scale are implemented in the services sector and households as in these sectors less costly measures are already implemented in the baseline scenario.

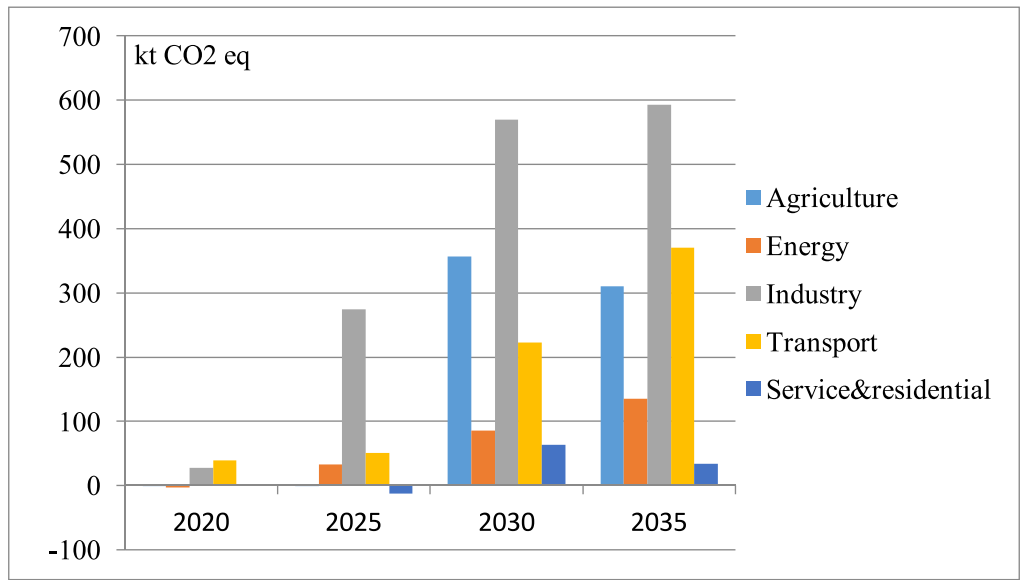

Fig. 2. GHG emissions reduction in the stabilisation scenario against the baseline scenario.

In the GHG emissions stabilisation scenario in 2030 against the baseline scenario the greatest contribution to the calculated $1301 \mathrm{kt} \mathrm{CO}_{2}$ eq reduction is from reduction measures in the industry followed by the transport and agriculture sectors.

In case the non-ETS sector has set the target to reduce GHG emissions in 2030 against 2005 by $10 \%$, to reach the target, apart from the measures in the stabilisation scenario, the transport sector should contribute considerably to GHG emissions reduction after 2025 (see Fig. 3).

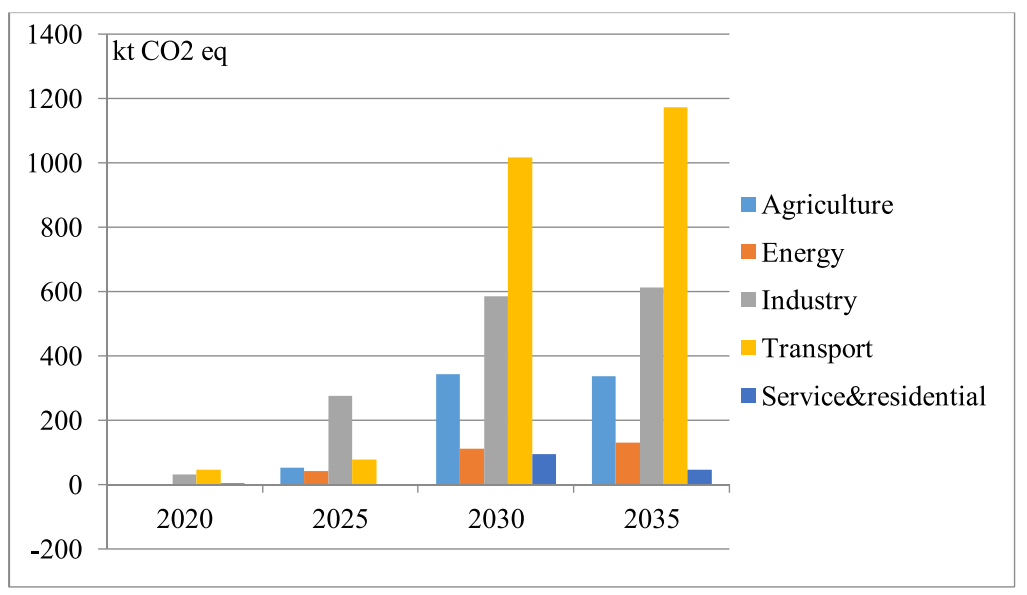

Fig. 3. GHG emissions reduction in the scenario with the 2030 reduction target against the baseline scenario.

As in the other sectors the GHG emissions reduction potential defined in the model is exhausted, bearing in mind the total optimal costs, the transport sector should provide almost half of the required GHG emissions reduction in 2030. 


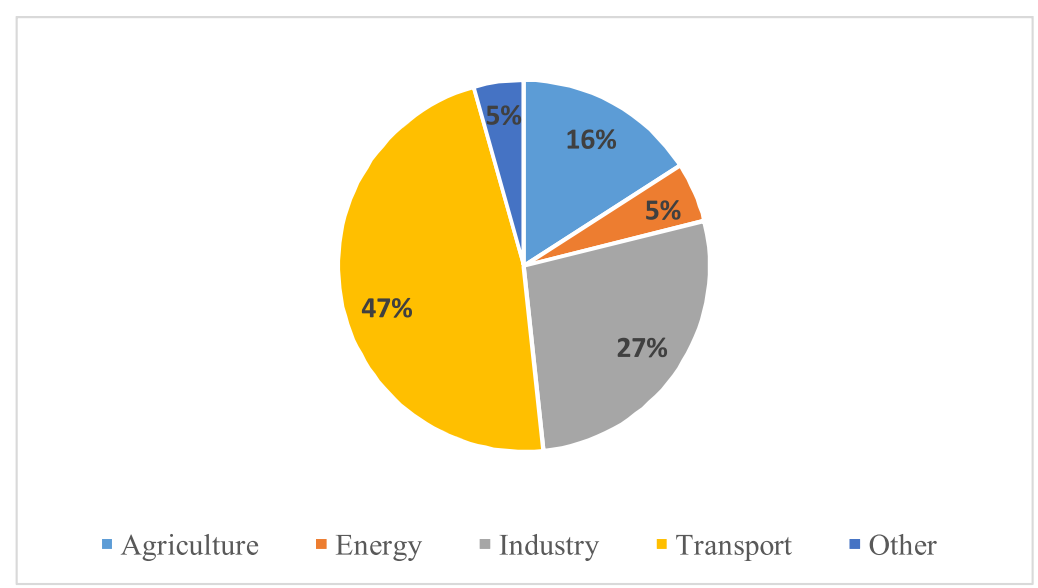

Fig. 4. Distribution of GHG emissions reduction according to sectors in the scenario with the 2030 reduction target against the baseline scenario.

\section{Role of Energy Efficiency and Impact upon GHG Emissions Reduction}

To assess the role of energy efficiency measures in GHG emissions reduction for reaching the targets, apart from the main set of alternative scenarios additional scenarios were developed (the scenario marked with E). In these scenarios, in addition to the already defined measures new packages of energy efficiency raising measures with additional potential and higher costs were included. Partly it can be interpreted as promoting the government policies by wider implementation of various energy efficiency raising measures. Figure 5 shows that in the GHG emissions stabilisation scenario these measures contribute to additional GHG emissions reduction in the services sector and households, thus substituting some more costly measures in the agriculture sector.

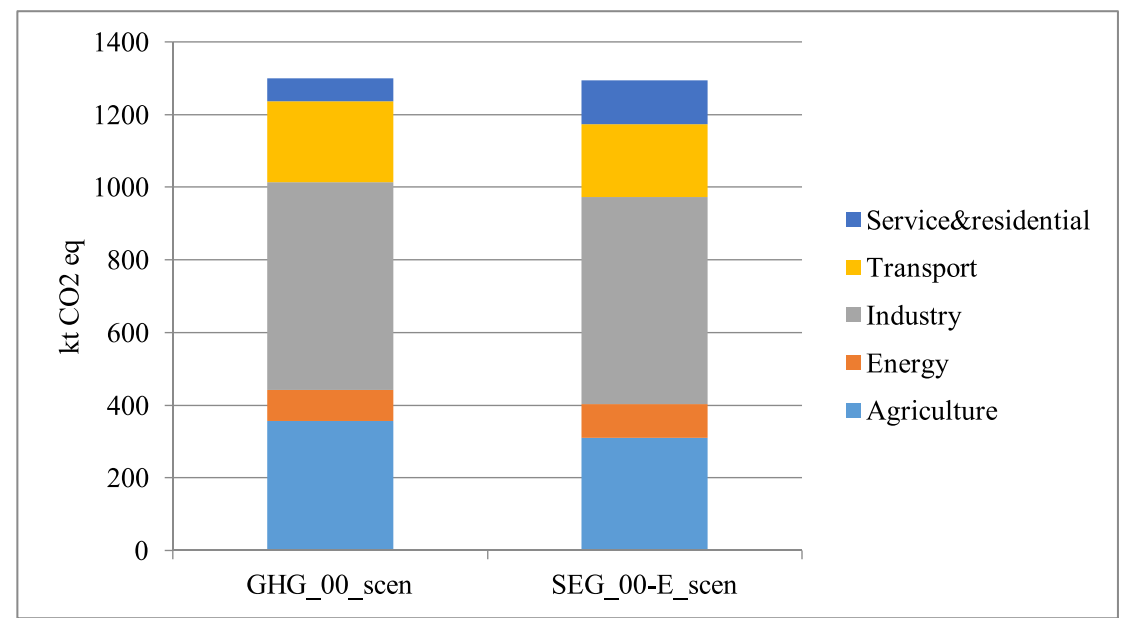

Fig. 5. Structure of GHG emissions reduction in the emissions stabilisation scenario in 2030 against 2005 based on a variety of available energy efficiency measures.

The scenario of GHG emissions reduction in 2030 against the level of 2005 envisages the implementation of additional energy efficiency measures in the ser- 
vices sector, households and industry. Thus, these measures substitute some more costly emissions reduction measures in the transport sector.

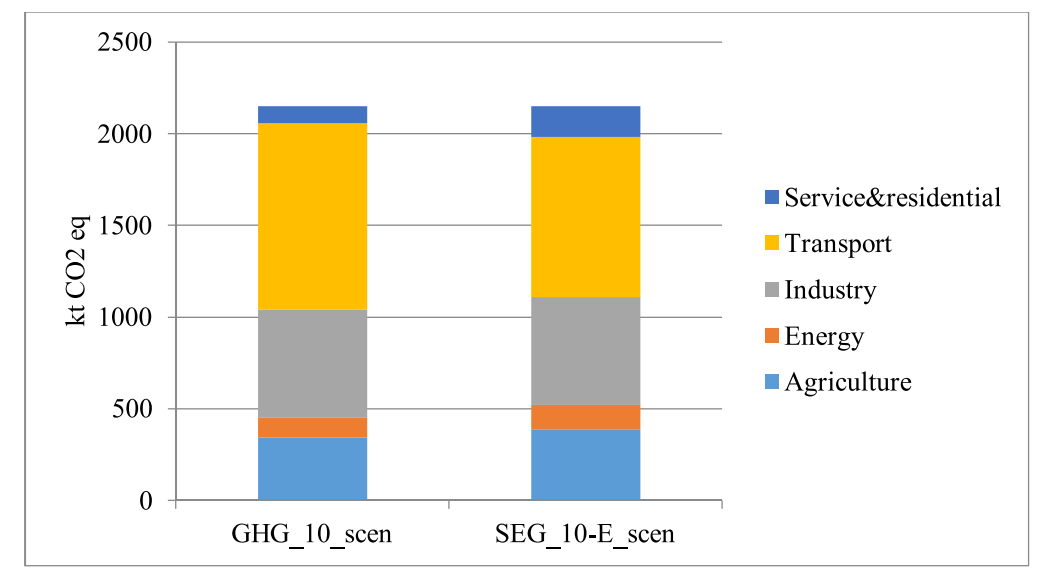

Fig. 6. Structure of GHG emissions reduction in the emissions reduction scenario in 2030 against 2005 based on a variety of available energy efficiency measures.

The modelling results reveal that additional energy efficiency measures in households are implemented to a full extent already in the GHG emissions stabilisation scenario (see Fig. 7). The results show that energy efficiency measures are cost effective for GHG emissions reduction with regard to the total optimal costs in the system.

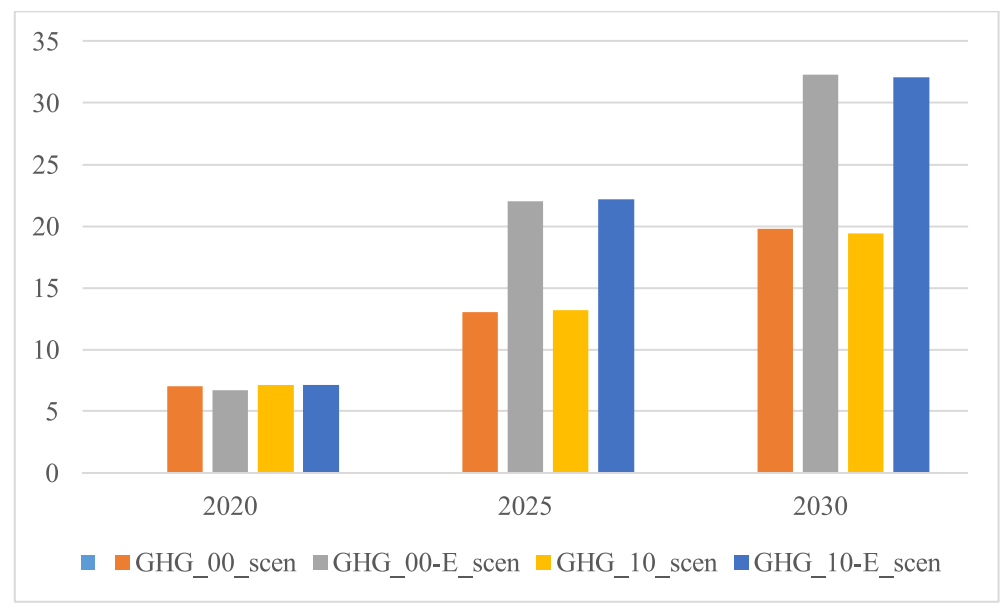

Fig. 7. Energy saved thanks to energy reduction measures in households in different scenarios.

Energy efficiency measures from the point of view of GHG emissions reduction abatement costs are among the measures with the lowest costs per reduced GHG unit (EUR/t $\mathrm{CO}_{2}$ eq). At the same time, it should be admitted that to implement these measures many obstacles need to be overcome and various policies are to be applied for promoting these measures. Attractive emissions abatement costs for energy efficiency measures determine additional gains of emissions reduction from these measures, i.e., lower costs for energy and fuel consumption. 
However, these measures often do not seem attractive to investors, as they are capital-intensive, i.e., with huge initial investments. In the actual investment environment with a limited amount of available investment, we are in a situation when an investor decides to invest in measures with lower capital intensity than in those with lower costs over the whole time period. In this way, the costs of emissions reduction measures increase continuously.

\section{CONCLUSIONS}

1. In the existing policy scenario (baseline scenario), the distribution of emissions among the sectors in the modelled non-ETS sector in 2030 is as follows: transport $(31.3 \%)$, agriculture $(33.9 \%)$, household and services $(12 \%)$, industry $(9.4 \%)$, energy $(4.8 \%)$, waste management $(5.2 \%)$ and the remaining part is formed by industrial processes and fugitive emissions, the use of solvents and other products.

2. The results obtained from the modelling of alternative scenarios allow making a conclusion that to reach the GHG emissions target in 2030 - to stabilise emissions at the level of 2005 or lower - it is necessary to implement the optimal scenario, i.e., to set higher GHG emissions targets in the non-ETS sector already for 2020. It is especially important in the scenario of emissions reduction in 2030 against the level of 2005.

3 . On the basis of the modelling results, it can be concluded that to implement a cost effective strategy of GHG emissions reduction first of all a policy should be developed that ensures effective absorption of the available energy efficiency potential in all consumer sectors. The next group concerning GHG emissions includes measures that are to be implemented in all non-ETS sectors (industry, services, agriculture, transport, and waste management).

4. GHG emissions reduction in the non-ETS sector may fall into several sub-groups: (I) the energy and industry sectors where a relatively small number of participants operate and it is possible to influence their activities by developing an investment environment by means of regulatory instruments; (II) this sub-group includes sectors where consumers are involved, i.e., buildings, transport, and waste management. The number of participants here is very great and the emissions reduction potential is considerable and with relatively low costs, especially regarding the improvement of energy efficiency of buildings. It is essential to develop versatile support policies for GHG emissions reduction measures. (III) Many participants and many small sources create emissions in the agriculture sector. Emissions are calculated very vaguely and, therefore, it is difficult to assess the impact of measures.

\section{ACKNOWLEDGEMENTS}

The present research has been supported by the Latvian National Research Programme 2014-2017 LATENERGI. 


\title{
REFERENCES
}

1. Country Factsheet Latvia. (2015). Commission staff working document. Brussels, SWD 230 final.

2. Fishbone, L.G., and Abilock H. (1982). MARKAL, a linear programming model for energy systems analysis: Technical description of the BNL version. International Journal of Energy Research, 5(4), 353-375.

3. Loulou, R., Goldstein, G., and Noble, K. (2004). Documentation for the MARKAL family of models. Energy technology systems analysis programme. Available at http://www. iea-etsap.org/web/MrklDoc-I_StdMARKAL.pdf.

4. Klavs, G., Kudrenickis, I., and Rekis, J. (2015). Development of Latvia greenhouse gas reduction policy: Modelling and analysis. In Proceedings of 5th International Multidisciplinary Scientific GeoConference SGEM (pp. 921-932), ISBN 978-619-7105-38-4 / ISSN 1314-2704

5. Klavs, G., Kudrenickis, I., and Rekis J. (2015). Bio fuel contribution in meeting renewable energy and climate policy targets in Latvia. In Proceedings of Conference "Engineering for Rural Development" (pp. 490-496), ISSN 1691-5976

6. Eurostat International Trade Data Base. Available at http://ec.europa.eu/eurostat/web/ international-trade/data/database.

7. IEA. (2014). World energy outlook 2014.

\section{ENERGĒTIKAS UN KLIMATA IETEKMES SAMAZINĀ ̌̌ANAS POLITIKAS ASPEKTU IEKL,AUŠANA LATVIJAS ENERG̣ĒTIKAS - VIDES MODELI}

\author{
G. Klāvs, J. Reķis
}

Kopsavi $1 \mathrm{kums}$

Rakstā atspoguḷoti rezultāti par pētījumu, kura mērḳis ir sekmēt Latvijas ilgtermiņa klimata politikas veidošanu, aprēķinot kopējās siltumnīcefekta gāzu (SEG) emisijas līdz 2030. gadam, novērtējot SEG emisiju samazināšanas trajektorijas ne-ETS sektorā pie atškirīgiem izvirzītiem emisiju samazināšanas mērḳiem un salīdzinot iegūtos rezultātus ar ES definētiem mērkịem klimata un energètikas satvarā 2030. gadam. Pētījumā tika izmantots MARKAL-Latvija modelis, kas izveidots izmantojot augšupvērstā, lineārās programmēšanas, optimizēšanas modeḷa MARKAL kodu, un kuram ir veikti papildinājumi klimata politikas integrētas novērtēšanas pilnveidošanai. Modelēšanas rezultāti par pētījumā izveidoto bāzes scenāriju, kas ietver Latvijas tautsaimniecības attīstības prognozes un esošos valsts klimata politikas noteiktos pasākumus, parādīja SEG emisiju pieaugumu ne-ETS sektorā 2030. gadā pret 2005. gadu par 19.1\%. SEG emisiju stabilizācijas un samazināšana 2030. gadā pret 2005. gadu tika modelēti un analizēti alternatīvajos scenārijos.SEG emisiju stabilizēšanas un samazināšanas ne-ETS sektorā scenāriju modelēšanas rezultātu analīze atklāja, ka lai īstenotu no izmaksu viedokḷa optimālu SEG emisiju samazināšanas stratēǵiju, pirmkārt ir jāsekmē enerǵijas efektivitātes pieejamā potenciāla izmaksu efektīva apgūšana visos enerǵijas patērētāju sektoros un nākošā SEG emisiju samazināšanas pasākumu grupa aptver visus ne-ETS sektorus (rūpniecība, pakalpojumi, lauksaimniecība, transports, atkritumu apsaimniekošana). 01.12.2016. 